\title{
The Icelandic news media in times of crisis and change
}

\author{
Valgerður Jóhannsdóttir, Adjunct Lecturer, Faculty of Political Science, \\ University of Iceland and PhD student, Department of Communication \\ and Arts, Roskilde University \\ Jón Gunnar Ólafsson, Associate Lecturer and PhD student, Department \\ of Media and Communications, Goldsmiths, University of London
}

\begin{abstract}
The news media around the world has experienced drastic changes in recent decades, and the Icelandic media is no exception. These changes originate in political, economic and not least technological developments. In this article we map key developments in the Icelandic media system and illustrate the changes it has undergone in the first decades of the $21^{\text {st }}$ century. Journalism and media studies are under-researched fields of study in Iceland, and the country is usually absent from comparative work in these fields. Often it is simply grouped together with the other four Nordic countries. We argue that the Icelandic media system differs from those countries in several ways. Whilst it has moved towards the liberal model there are also indications of increased partisanship in the media in the last decade. The smallness of the media system has made it more vulnerable to the increasing competition and commercialisation in the digital era, and Iceland was particularly badly hit by the financial crisis in 2008 . News media companies in Iceland are struggling financially, several media outlets have come and gone, mergers have been frequent and trust in the media is low. The view that some sort of public support is required to secure an independent media and high-quality journalism is gaining ground in Iceland. This could lead to its media system becoming more similar to the democratic corporatist Nordic countries than is the case now.
\end{abstract}

Icelandic Review of Politics and Administration. Vol. 14, Issue 1. Special issue on power and democracy in Iceland (189-210) (C) 2018 Contact: Valgerđur Jóhannsdóttir, vaj@hi.is

Article first published online May $31^{\text {st }} 2018$ on http://www.irpa.is

Publisher: Institute of Public Administration and Politics, Gimli, Sæmundargötu 1, 101 Reykjavík, Iceland

Stjórnmál \& stjórnsýsla. 1. tbl. 14. árg. 2018. Sérhefti um vald og lýðræđi á Íslandi (189-210) Fræđigreinar

C 2018 Tengiliđur: Valgerđur Jóhannsdóttir, vaj@hi.is

Vefbirting 31. maí 2018 - Birtist á vefnum http://www.irpa.is

Útgefandi: Stofnun stjórnsýslufræđa og stjórnmála, Gimli, Sæmundargötu 1, 101 Reykjavík

DOI: https://doi.org/10.13177/irpa.a.2018.14.1.9

This work is licensed under a Creative Commons Attribution 3.0 License. 
Keywords: News media; media system; financial crisis; journalism; democracy; Iceland.

\section{Introduction}

The Icelandic news media has undergone substantial changes in recent years and is facing many challenges which can undermine the important democratic role it plays in society. This development is not unique to Iceland. The news media around the world has experienced drastic changes in recent decades. They originate in political, economic and technological developments, such as in the deregulation of the media sector in many countries, the internet and the digital revolution (Lee-Wright et al. 2012; Nielsen 2012; Fenton 2010; Currah 2009; Hardy 2008; Herkman 2008; Hallin \& Mancini 2004). These changes have altered the way people communicate, seek information and use the media, and they have thoroughly shaken the financial foundation upon which the news media has rested. News is usually free and easily available on the internet, and as increasingly more readers migrate online, so does the advertising revenue, of which global companies such as Google and Facebook claim increasingly larger shares (Ohlsson \& Facht 2017). The reach of traditional media is declining, as is the number of journalists in most Western countries, and research indicates that tougher competition and audience fragmentation has led to increasing commercialisation in the news media. The digitisation of the media landscape has accelerated, and the advent of social media and smartphones has made the news media landscape even more complicated and uncertain. The new information technology has a strong foothold in the Nordic countries, and Iceland is no exception.

The financial crisis that rocked the economies of countries in Western Europe in 2008 was a blow to a media industry already in turmoil. Iceland was particularly badly hit by the financial crisis, and the ensuing political and economic turmoil in the country has received substantial academic attention, such as from political scientists, economists, sociologists and historians (Indriðason et al. 2017; Bernburg 2016; Johnsen 2014; Jónsson 2009; Jóhannesson 2009). Less attention has, however, been paid to investigating developments in the Icelandic media in the aftermath of the crisis even though the crisis affected the media in many ways. Between 2007 and 2010 the revenues of media companies declined by approximately a quarter, and they are still 17\% lower than before the financial crisis (Statistics Iceland 2018). News media companies in Iceland are struggling financially, several media outlets have come and gone, mergers have been frequent and the number of journalists working in the media has still not regained its pre-crisis level (Guðmundsson 2016). These changes and their implications warrant further investigation.

The aim of this article is to assess key developments in the Icelandic media system and illustrate the changes it has undergone in the first decades of the $21^{\text {st }}$ century. We examine the extent to which the current situation of the Icelandic news media is different to that of the media in the neighbouring countries. Moreover, we discuss the extent to which the difficulties of the news media in Iceland are likely due to global changes 
affecting the media elsewhere and the extent to which they could be a result of the vulnerability of the small Icelandic media market and the severe financial crisis that hit the country in 2008 .

The article begins with a brief overview of the news media landscape in Iceland. Subsequently the development of the media market in recent years is examined and placed in an international, mainly Nordic, context. We utilise Hallin and Mancini's (2004) three models of media and politics for our analysis. Iceland is usually absent from comparative work in media and communication studies, and yet it is often mentioned together with the other four much larger Nordic countries and simply discussed as some sort of Nordic model. In the article we argue that the Icelandic system is in fact dissimilar from the other four countries in several ways. It has moved towards the liberal model in recent years, but there are also indications of increased partisanship in the media in the last decade. Following this, the article discusses the impact of the financial crisis on the news media in Iceland, the criticism it received for its performance in the years leading up to the financial crisis, trust in the media and its economic situation.

Journalism and media and communication studies are in general under-researched fields of study in Iceland. Moreover, statistics concerning the structure and development of the media industry are more limited in Iceland than in many other European countries. Public authorities do not monitor the media market to the extent done in the other Nordic countries, nor has the industry itself agreed upon the gathering of common key indicators (Ohlsson 2017). In this article we draw on the somewhat limited research on journalism in Iceland as well as data from various secondary sources, mainly statistics and reports from Nordicom, Statistics Iceland, Gallup, Media and Market Research (MMR), the Worlds of Journalism Study and the World Values Survey.

\section{The Icelandic media landscape}

The media system in Iceland transformed in the last two decades of the $20^{\text {th }}$ century, and this transformation corresponded to changes in Icelandic society, including the political and economic systems (Harðarson 2008). In the 1970s and onward the political parties' hold on society in general, and the media in particular, began to subside. Political parallelism in the media gave way to a more market-driven media, and professionalism in journalism increased. The political parties' hold on the Public Broadcasting Service started to lessen in the last decades of the $20^{\text {th }}$ century (Guðmundsson 2009; Harðarson 2008). The last political party newspaper ceased publication in 1997, and the first Icelandic online news publication appeared in 1998 (Friðriksson 2000). At the beginning of the $21^{\text {st }}$ century the first free daily newspaper was launched (Karlsson 2004).

The media system that emerged in Iceland in the beginning of the $21^{\text {st }}$ century was characterised by a high supply of all forms of media. The quantity and diversity are perhaps greater than might be expected in a country of around 350,000 people (Statistics Iceland n.d.). At the time of writing there are two national daily newspapers published in the country, two weeklies and one biweekly. There are several online news sites, with no links to traditional media, which play an increasingly prominent part in the provision of 


\section{STJÓRNSÝSLA}

daily news. There are also several regional and local papers, but most of them are small, and local media has always been weak in Iceland (Statistics Iceland n.d.; Guðmundsson 2006). Traditional media and online-only media all make extensive use of social media. Icelanders can choose between 12 domestic TV stations and 19 radio stations. Most are, however, primarily in the business of entertainment, and only two operate a news service (Fjölmiðlanefnd n.d.). In addition, there are countless foreign media channels available through satellite, broadband and internet technologies.

The media market has to a large extent been dominated by three media companies, in terms of revenue and audience share as well as the number of journalists employed (Ohlsson 2015; Guðmundsson 2013). These are the Public Broadcasting Service RÚV and two private media companies, 365 Media and the publishing company Árvakur. According to Guðmundsson (2016) 70\% of the 330 members of the Union of Icelandic Journalists, registered as working for a media company in 2015, were employed at these three companies.

365 Media has been by far the biggest private media company in Iceland, operating several TV and radio stations, newspapers and online sites as well as magazines and telecoms. However, in March 2017 the broadcasting part of 365 Media was sold to Sýn hf (Vodafone Iceland). The Icelandic Competition Authority approved the deal in October 2017 (Samkeppniseftirlitið 2017a). 365 Media was the only private actor in broadcasting that had its own news operation, but from December 2017 that role was taken over by Sýn hf. as the newsroom of Channel 2 (Stöð 2) and radio Bylgjan were included in the deal. The second most read online news site, visir.is, was also included (Samkeppniseftirlitið 2017a). The free paper Fréttabladid, which is the most read newspaper in Iceland, is still in the hands of 365 Media. The principal owner ${ }^{1}$ is an independent investor with interests in other sectors (Fjölmiðlanefnd, n.d.). According to an agreement with the Icelandic Competition Authority, Sýn hf is committed to operating a news service for at least three years unless significant, negative developments in market conditions call for a change (Samkeppniseftirlitið 2017b). Sýn hf is a publicly traded company, and its biggest shareholders are pension funds and insurance companies.

The second largest private company is Árvakur. It publishes Morgunbladid, Iceland's oldest newspaper, with historical links to the conservative Independence Party. The paper dominated the newspaper market for most of the $20^{\text {th }}$ century, both in circulation terms and revenue. However, it lost its leading position when free papers entered the scene. Its online counterpart, mbl.is, has, though, from its foundation in 1998 been the most read online news site in Iceland. As of recently, Árvakur also operates a radio station and a book publishing company. Árvakur was near bankruptcy after the financial crash in 2008 and was taken over by one of the banks and sold to a group of investors with ties to the fishing industry in 2009 (Kolbeins 2015; Guðmundsson 2013). The new owners hired as Editor-in-Chief Mr. Davíð Oddsson, a leading politician for decades in Iceland, former prime minister, leader of the Independence Party and subsequently the governor of the Central Bank when the Icelandic banks collapsed. The hiring of Mr. 
Oddsson was highly controversial, and many are said to have cancelled their subscription to the paper in protest (Árnason et al. 2010; Fontaine 2009; DV 2009).

In addition to these two large private companies, there is Iceland's Public Service Broadcasting, RÚV, which has maintained a strong and stable position in the media market despite increasing competition, not least by online media (Ohlsson 2015). Table 1 shows the market share of the largest channels in Iceland (TV and radio) from 2005 to 2016. Table 2 illustrates RÚV's market share in comparison to PBS stations in the other Nordic countries.

Table 1. Broadcasting companies' audience marketing share 2005-2016. Share of viewing/listening time (\%)

\begin{tabular}{llrrrrrrrrrrrr}
\hline & Channel & $\mathbf{2 0 0 5}$ & $\mathbf{2 0 0 6}$ & $\mathbf{2 0 0 7}$ & $\mathbf{2 0 0 8}$ & $\mathbf{2 0 0 9}$ & $\mathbf{2 0 1 0}$ & $\mathbf{2 0 1 1}$ & $\mathbf{2 0 1 2}$ & $\mathbf{2 0 1 3}$ & $\mathbf{2 0 1 4}$ & $\mathbf{2 0 1 5}$ & $\mathbf{2 0 1 6}$ \\
\hline Iceland $^{1}$ & RÚV-TV & 44 & 45 & 49 & 50 & 48 & 50 & 50 & 57 & 58 & 62 & 51 & 53 \\
& 365 Media TV & 39 & 34 & 32 & 33 & $\mathbf{3 7}$ & $\mathbf{4 0}$ & $\mathbf{4 2}$ & $\mathbf{3 5}$ & $\mathbf{3 3}$ & $\mathbf{3 3}$ & 31 & 29 \\
& Other & 17 & 21 & 19 & 17 & 15 & 10 & 9 & 7 & 8 & 5 & 18 & 18 \\
& Total & 100 & 100 & 100 & 100 & 100 & 100 & 100 & 100 & 100 & 100 & 100 & 100 \\
& & & & & & & & & & & & \\
RúV - Radio & 53 & 51 & 54 & 54 & 55 & 47 & 55 & 50 & 51 & 51 & 51 & 51 \\
& 365 - Bylgjan & 22 & 24 & 24 & 33 & 30 & 35 & 31 & 34 & 34 & 34 & 33 & 34 \\
& Other private radio & 25 & 25 & 23 & 13 & 15 & 18 & 14 & 16 & 15 & 15 & 16 & 15 \\
All private radio & 47 & 49 & 47 & 46 & 45 & 53 & 45 & 50 & 49 & 49 & 49 & 49 \\
Total & 100 & 100 & 100 & 100 & 100 & 100 & 100 & 100 & 100 & 100 & 100 & 100 \\
\hline
\end{tabular}

(Age: 12-80)

Source: Nordicom. TV broadcasting companies' audience shares 2000-2016 and radio channels' daily reach 2000, 20052016. Age range: $12-80$ years old.

Table 2. Public service TV audience shares in the Nordic countries 2005-2016 (\%)

\begin{tabular}{lcccccccccccc}
\hline & 2005 & 2006 & 2007 & 2008 & 2009 & 2010 & 2011 & 2012 & 2013 & 2014 & 2015 & 2016 \\
\hline DR & 33 & 33 & 33 & 29 & 27 & 28 & 28 & 29 & 31 & 34 & 34 & 37 \\
TV 2 & 36 & 34 & 33 & 31 & 29 & 28 & 27 & 24 & 23 & 24 & 24 & 25 \\
Yle & 44 & 45 & 44 & 45 & 44 & 45 & 44 & 42 & 42 & 44 & 43 & 45 \\
RÚV & 44 & 45 & 49 & 50 & 48 & 50 & 50 & 57 & 58 & 62 & 51 & 53 \\
NRK & 44 & 44 & 42 & 38 & 39 & 41 & 41 & 41 & 41 & 38 & 40 & 39 \\
SVT & 40 & 38 & 35 & 34 & 33 & 35 & 35 & 37 & 35 & 35 & 36 & 36 \\
\hline
\end{tabular}

Source: Nordicom: Public service TV audience shares 2000-2016.

RÚV has, since 2009, been financed by a broadcasting tax instead of a license fee, as in the Scandinavian countries (a similar system was taken up in Finland in 2013) (Schweizer \& Puppis 2017; Ohlsson 2015). Furthermore, RÚV has from its foundation in 1930 


\section{STJÓRNSÝSLA}

been allowed to carry advertisements and advertising sales amount to approximately one-third of its revenue (RÚV 2015). In this sense RÚV has always also been a commercial station (Broddason \& Karlsson 2005), but it is not permitted to sell advertisements online. Its share of the total revenue of the media is around $20 \%$ and has been more or less the same since the turn of the century (Statistics Iceland 2018).

Another large actor in the media market is the company Frjáls fjölmiðlun, which recently bought the media outlets of Pressan ehf. This included the tabloid newspaper $D V$ and its online counterpart $d v$.is and several online news and entertainment sites. $D V$ has had a somewhat rocky past. Its ownership has changed hands several times and so has its publication frequency. It is now published once a week (Guðmundsson 2017).

In addition, the Icelandic news media market encompasses one weekly business paper, Vidskiptabladid, and two national online news sites that do not have links to traditional media. Both online news sites, stundin.is and k.jarninn.is, were founded by journalists, and, though not the most read sites in the country, they have been quite influential and often cited in the mainstream media. Stundin.is is subscription-based and is also published in print twice a month. It is mostly owned by the journalists that founded it, and no shareholder has a share larger than 12\% (Fjölmiðlanefnd n.d.). Kjarninn is financed by advertising, and its content is open to everyone, but it also receives substantial revenue from a monthly voluntary subscription (RÚV 2017). It recently started publishing a free monthly printed news and lifestyle magazine in cooperation with a magazine publication company (mbl.is 2017). The largest shareholders are two investors from the IT industry, with a 16-17\% share respectively and two of the founders with a $12-14 \%$ share (Fjölmiðlanefnd n.d.).

It is a distinctive characteristic of the Icelandic press market that it has "produced neither elite-oriented quality papers nor extremely populistic tabloids" (Karlsson 2004, 242). In a market as small as the Icelandic one there is little room for readership segregation based on purchasing capacity and other socio-economic divisions, and Icelandic newspapers mostly cater for readership among the general population. The strong position of the free papers in the Icelandic media market is also somewhat unique. In 2010 Iceland and Luxemburg were the only European countries where the penetration of free newspapers was higher than that of their paid for counterparts (Bakker 2013; see also Karlsson 2009). Secondly, the free papers have been general purpose papers with serious coverage of domestic and international news, not down-market tabloids, and delivered to people's homes (Bakker 2008).

Newspaper circulation and readership in Iceland has traditionally been very high, but it is declining (Figure 1). The publication of the free paper Fréttabladio in $2002^{2}$ did increase newspaper penetration (Karlsson 2004), or at least postponed its decline, but its circulation is also dwindling. 


\section{STJÓRNSÝSLA}

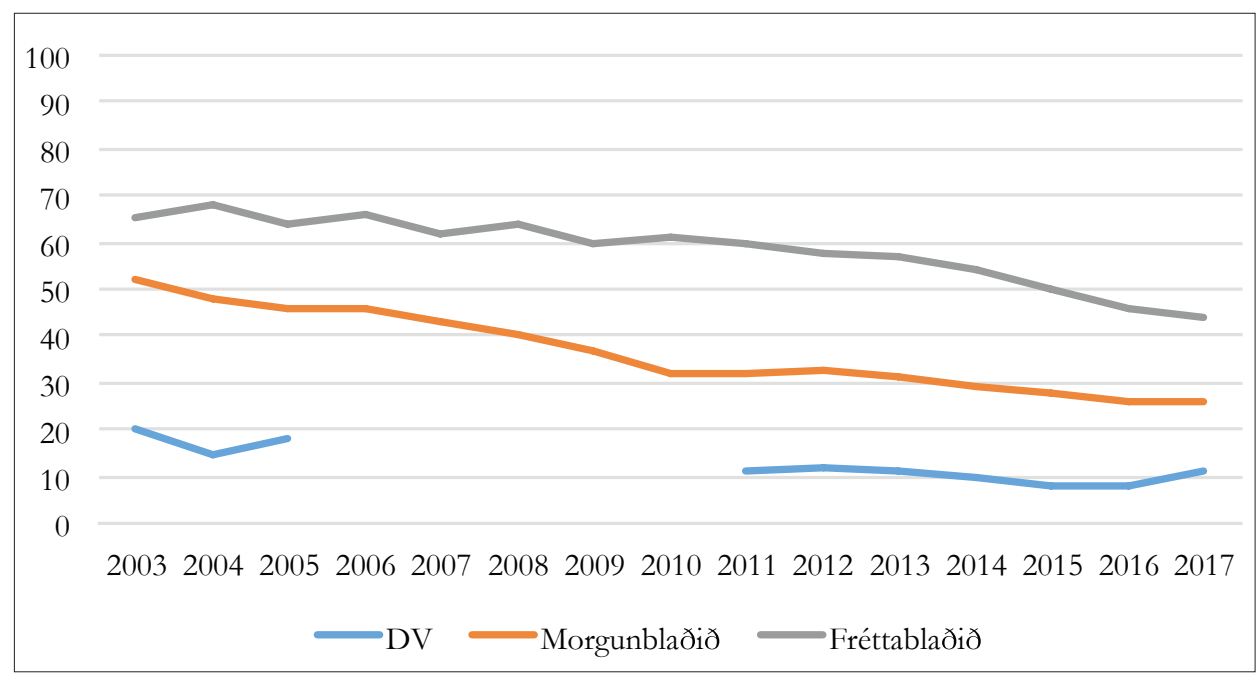

Source: Gallup. DV did not take part in the readership measure in 2005-2011.

Figure 1. Newspaper readership in Iceland 2003-2017 (\%)

Whilst newspaper readership has been in steady decline for a long time, online news reaches increasingly more people. Research has indicated that despite the vast amount "of information available online, the mainstream established news outlets still dominate our news consumption across all platforms" (Fenton 2016,157). This has been the case in Iceland, where by far the most read online news sources are Árvakur's mblis and visir. $i s$, which formerly belonged to 365 Media and now to Sýn hf (Figure 2).

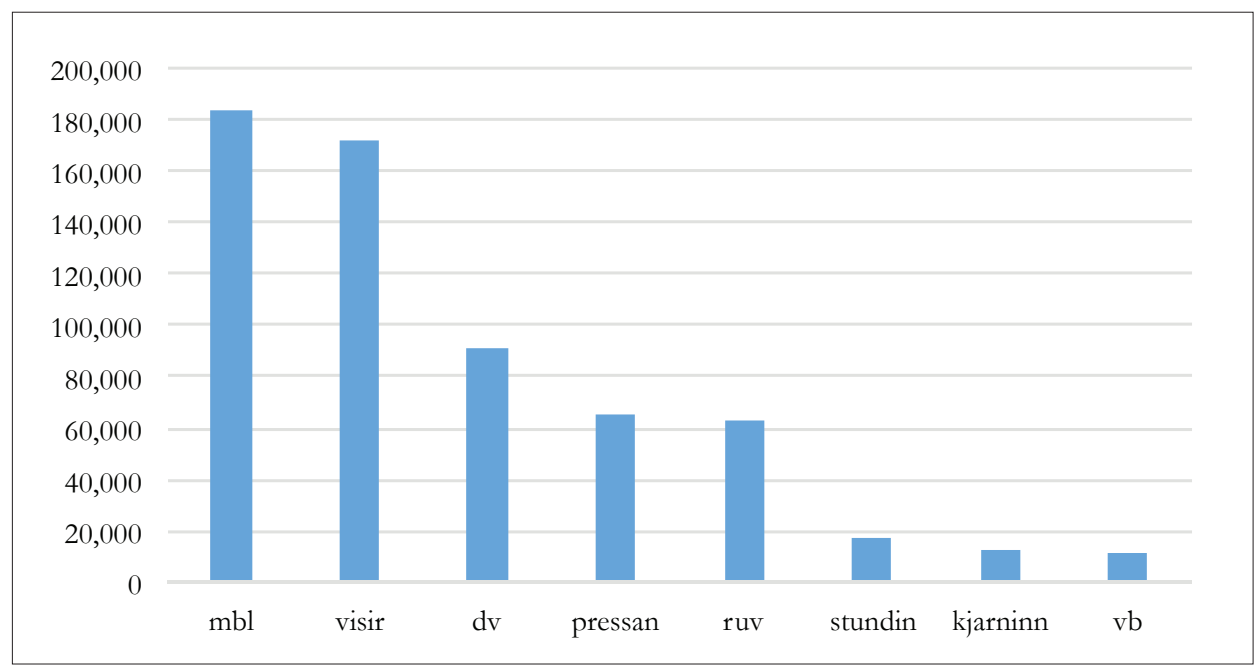

Source: Gallup. Week 392017.

Figure 2. Daily average reach of main online news sites in Iceland 


\section{STJÓRNSÝSLA}

Iceland is among the richest countries in the world (Gregson 2017) and is technologically advanced, for example it is in the lead in the ICT Development Index 2017 (International Telecommunication Union 2017). Like in the other Nordic countries the internet is widely spread and used. According to the most recent worldwide comparative internet statistics, Iceland is now the only country in the world with $100 \%$ internet penetration (Internet World Stats 2017). Norway is very close, with 99,6\% of the population with internet access; in Denmark the percentage is 97\%, and in Finland and Sweden it is $93 \%$. The average internet penetration in Europe is $80 \%$. Smartphones are also widely spread in Iceland and among 18-49-year-olds almost universal, that is, used by $96 \%$ (Markaðs- og miðlarannsóknir 2016). Social media is extensively used, with Facebook being by far the most popular platform. According to a Gallup survey from 2017 a total of $92 \%$ of Icelanders used Facebook, whilst the second most popular platform was Snapchat $(62 \%)$, and Instagram was in third place (44\%). Icelanders also appear to be more active on social media than their Nordic cousins (Nordicom n.d. b).

In economic terms, the Icelandic media expanded tremendously towards the end of the past century and in the first years of the $21^{\text {st }}$ century. From 1995 to 2008 television revenue more than doubled, in radio the revenue growth was 56\% and in newspapers 51\% (online editions included) (Statistics Iceland 2018; Karlsson 2009). The number of publications and outlets grew considerably. At the peak in 2006-2007, Iceland had five national daily newspapers and three TV stations delivering news (one 24/7 news channel) (Jóhannsdóttir 2015). The new media system that emerged at the beginning of the $21^{\text {st }}$ century was, however, not only characterised by a high supply of all forms of media but also by increasing commercialisation, convergence and intense ownership concentration in private media (Harðarson 2008). Karlsson noted that acquisitions, takeovers and mergers had become a noticeable part of the media market as media companies tried to exploit the economies of scale and scope. New technology also "encouraged horizontal and diagonal integration and cross-ownership both within the more traditional media and between media and telecommunications" (Karlsson 2006, 25). Concern over increasing ownership concentration in the media had begun to mount in the early years of the century and resulted in one of the fiercest political debates in the country in decades (Axelsson \& Gylfadóttir 2015; Harðarson 2008), but it was not until 2011 that Iceland's first Media Act was passed, and it did not include any restrictions on media ownership (Act no. 38/2011).

Puppis (2009) has argued that small states may allow for cross-media ownership and do without restrictions on ownership concentration to foster a strong domestic media industry, and that is precisely the argument used in the statement that accompanied the Media Act in 2011 (Act no. 38/2011). However, media companies are required to make their ownership public. In 2012 changes were made to the act, and competition authorities were given the power to intervene if changes in ownership are thought to pose a threat to media pluralism (Act no. 54/2013). The law also had several new provisions intended to strengthen editorial independence and protect journalists against improper ownership influence as well as a clause on the rights of journalists to protect their 


\section{STJÓRNMÁL \& \\ STJÓRNSÝSLA}

sources. With the Media Act a new administrative commission was established (The Media Commission), which carries out the supervision of the media market according to the Media Act and attends to day-to-day administration in the fields covered by the law (Act no. 38/2011).

In 2004 Karlsson found that commercialisation had increased considerably around the turn of the century, not least due to the arrival of free papers, and argued that this had led to a definite trend towards more entertainment news (Karlsson 2004). Guðmundsson (2012) came to a similar conclusion in a study of the three main Icelandic newspapers published from 2008-2010. The proportion of soft news in major printed newspapers had increased considerably from previous years. In all three papers the soft news constituted more than half (51-56\%) of the total number of news items analysed compared to $24-27 \%$ soft news and $73-76 \%$ hard news in 2005. Guðmundsson also observed a high level of similarity in content and suggested that homogenisation was increasing considerably in the Icelandic press. The findings from a study of hard and soft news coverage in two major Icelandic newspapers and their online counterparts indicated that the daily press published less political and economic news in 2013 than in 2005, whereas the amount of soft news had increased significantly, particularly on the online news sites (Jóhannsdóttir 2018).

\section{A (not so) Nordic media system}

Nordic media is often used as an example of media industries that have been able to provide its users with socially relevant content and at the same time flourish as successful businesses. Furthermore, Nordic citizens repeatedly rank high in international comparisons of political knowledge (Curran et al. 2009; McQuail 1992). The media system in Iceland has in many respects developed in a way similar to the other Nordic countries, but there are also important differences.

Harðarson (2008) analysed the Icelandic media system using Hallin and Mancini’s framework of three models of Western media systems, introduced in their influential book Comparing Media Systems (Hallin \& Mancini 2004). The liberal model, which persists in its purest form in the US, is characterised by "a relative dominance of market mechanisms and of commercial media"; the polarised pluralist model is marked by "integration of the media into party politics, weaker historical development of commercial media, and a strong role of the state" and is found primarily in Southern Europe; and the democratic corporatist model can be said to be a blend of the other two, with its "historical coexistence of commercial media, and media tied to organized and political groups, and by a relatively active but legally limited role of the state". The democratic corporatist model is to be found in Northern Europe, and the Nordic countries are said to be the best example (Hallin \& Mancini 2004, 11).

Iceland was not included in Hallin and Mancini's study. Harðarson (2008) places the country within the democratic corporatist model but makes a distinction between the old system, which in some aspects shared features with the polarised pluralist model, and the new media system of the $21^{\text {st }}$ century, which "clearly has moved towards the 


\section{STJÓRNSÝSLA}

liberal model in many respects" (Harðarson 2008, 79). Other Nordic academics have argued that neo-liberalism has been more influential in Iceland than in the other Nordic countries and that its media system has moved closer to the liberal model (Ahva et al. 2017; Syvertsen et al. 2014). Corporatism is less developed in Iceland than in the other Nordic countries, and state involvement has been limited to the Public Broadcasting Service, whilst all other media outlets are based on commercial grounds. Private media has not been subject to regulation or requirements aimed at ensuring media pluralism and public service journalism, like private media in the other Nordic countries has (Karlsson \& Broddason forthcoming; Guðmundsson \& Kristinsson 2017; Jónsson 2014; Harðarson 2008). The press does not receive any direct subsidies, and the state's involvement in the newspaper industry has been very limited. "To this extent, Iceland does not fit into the model of an active state vis-a-vis the media that is commonly used to describe the Nordic media system" (Ohlsson 2015, 27).

Karlsson noted in 2004 that "...there has strangely enough been virtually unanimous agreement across the political spectrum from the right to the left, contending that the press and the private media in general should be left to themselves" (Karlsson 2004, 227-28). Before the financial crisis in 2008 that was also the prevalent view of private media companies and the Union of Icelandic Journalists. However, this view seems to be changing, and increasingly suggestions are made that some sort of public support is required to secure an independent media and high-quality journalism (Guðmundsson 2012b, 22). In July 2016 the directors of five broadcasting companies made a public call to the government and members of parliament (MPs) to make the "necessary, appropriate and overdue changes" (authors' translation) to ensure the competitiveness of private media in Iceland (mbl.is 2016). A committee established in December 2016 to examine the economic situation of private media in Iceland concluded that it was worrying in light of the media's important role in democratic societies (Menntamálaráðuneyti 2018). The committee put forward several proposals to ease the difficulties, for example lowering the value-added tax (VAT) on online media subscription, refunding up to $25 \%$ of news production cost and removing the Public Broadcasting Service from the advertising market. At the time of writing the Ministry of Education, Science and Culture is reviewing and evaluating the proposals (Friðjónsdóttir 2018; Fréttablaðið 2018).

Whilst the media system has moved towards the liberal model there are also indications of increased partisanship - or instrumentalisation - of the media in the last decade. Owners of private media companies have openly claimed that their objective was to influence the public sphere. In 2009 a group of investors with interests in the fishing industry acquired the publishing company Árvakur. In a TV interview one of the shareholders said that the clear objectives of the investment had been to influence public debates and political decisions on controversial political issues at the time (Hringbraut 2016). Another example is the decision by Exista (a big investment company) in 2007 to invest in the "not so profitable" business paper Vidskiptabladid. One of the owners said this was necessary since almost all other media outlets were in the hands of the country's then two other main business blocks (Exista 2007). Guðmundsson 


\section{STJÓRNMÁL

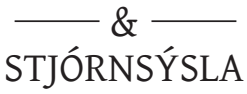

(2013) argues that elements of political parallelism have carried over into the new era of commercial media. The perception of a connection between traditional media and political parties is deep-rooted, and politicians in particular appear to have very little confidence in journalistic professionalism or the impartiality of the news media. Guðmundsson argues that the historical proximity of political parallelism, a relatively recent professionalisation of journalists, an unregulated media environment and an "extreme ownership concentration of the media, where ownership powers and political parties became mixed with each other" have led to the development of a "Politically Commercial Media System" $(2013,510)$. Ohlsson and Facht also remark that the Icelandic media market is "characterised by a comparatively tight bond between the political sphere and the domestic enterprise sector" and that links with external stakeholders contribute "to the relationships in the media market being more problematic than they are in the other Nordic countries" (2017, 93).

Iceland has a history of the state playing a large role in the economy (Kristinsson 1996), just like the states in the polarised pluralist countries in Southern Europe. Hallin and Papathanassopoulos argue that this is "crucial to understanding why capitalists are so deeply involved in politics that they will waste their money starting or buying newspapers: political influence is crucial to success in business" $(2002,183)$. A weak media regulatory body is another element Iceland has in common with the polarised pluralist countries (Hallin \& Papathanassopoulos 2002). The Icelandic Media Commission has broad function and duties but has from the start been underfinanced and understaffed (Jóhannsdóttir 2015). Its board of five and staff of three are responsible for supervising the Icelandic media market, both private media and the PBS, in accordance with Iceland's media legislation. This includes collecting and publishing data about the media market as well as handling complaints about individual media outlets' conduct. The commission's role is also to promote media literacy and diversity in the media and to guard freedom of speech and the public's right to information, to name but a few of its many duties (Fjölmiðlanefnd n.d.).

As discussed above, RÚV, the Public Broadcasting Service, holds a very strong position in the media market in Iceland, even in a Nordic comparison. It appears to retain a high level of legitimacy and, as will be discussed later, enjoys far more trust than other media in Iceland. Hallin and Mancini $(2004,167)$ posit that the Nordic countries tend to organise their PBS companies in "the direction of the professional model, according to which the running of Public Service Broadcasting is left to professionals in order to avoid political involvement". Moe and Mjøs also argue that the "running and supervision of Public Service Broadcasting in the Nordic countries are characterized, although in different ways and to varying degrees, by a separation between the institutions and the political powers" (2013, 88). However, these studies did not include Iceland, and Karlsson and Broddason (forthcoming) argue that RÚV enjoys less institutional autonomy than PBS companies in the other Nordic countries and that it has been subject to more political interference. Policy and regulations around the Nordic PBS companies have generally been rather stable, whereas legislation regarding RÚV has been subject to 


\section{STJÓRNSÝSLA}

frequent changes, depending on the composition of the political majority in parliament at the time. Kristinsson's (2012) study of party patronage in Iceland illustrates attempts by political parties to gain control over not just the Public Broadcasting Service but also private media companies since the media is seen as being of strategic importance in politics. In 2013 RÚV was made a state-owned limited company. This was said to increase its autonomy from the legislative and executive powers. However, it has been argued that the change from a license fee to a broadcasting tax to finance RÚV's operations has created a very unclear situation for the company and made it more dependent on the state (Engblom 2013).

A high degree of journalistic professionalism is a characteristic of both the democratic corporatist and liberal models (Hallin \& Mancini 2004), defined in terms of autonomy, professional norms and a public service orientation. Professionalism in journalism began to develop in Iceland somewhat later than in the other Nordic countries. The reasons are primarily rooted in the stronghold of the party press, which meant that politics and political views were an important indicator of a person's ability to work in the media, whilst professionalism was not held in particularly high regard in the field. This changed rapidly as the politicians' hold on the media began to weaken (Guðmundsson 2011). The education of journalists has greatly improved, and just over two-thirds of Icelandic journalists have a university degree (Kolbeins 2012). However, in an international context this is not particularly high. Data from the Worlds of Journalism Study show that in 53 of the 67 countries studied, $75 \%$ or more of the journalists have some form of a university education. Furthermore, formal education in journalism is not nearly as common in the Icelandic media as it is in the other Nordic countries. A quarter of Icelandic journalists have a formal degree in journalism or media studies, compared to $56 \%$ in Finland, 64\% in Norway, 68\% in Sweden and 82\% in Denmark. In fact, according to the Worlds of Journalism Study, of the 67 countries that took part, only in Bhutan (23\%) and Japan (12\%) are the percentages of journalists with journalism degrees lower than in Iceland (Worlds of Journalism Study n.d.).

Professional norms are widespread among Icelandic journalists. According to Ahva et al. (2017) journalists in Iceland (like their Nordic colleagues) consider objective reporting to be very important in their work and see themselves as detached watchdogs. Their professional identity is also one of autonomy, experiencing little influence from politics or economic forces in their daily work (Ahva et al. 2017; Kolbeins 2012; Nord 2008). However, another study on the state of journalistic professionalism in Iceland showed that although oriented towards public service, journalists "are undermined by the realities of the media market” (Guðmundsson \& Kristinsson 2017, 17). The study identified four factors that intensified the pressure journalists experience in their everyday work, including the technological competence required, increasing time spent on interacting with users, the growing professionalisation of special interests and PR pushing content to the media and not least the increasing competition and commercialisation pushing journalists to consider what might sell. The authors conclude, as do Strömback and Karlsson (2011) in their study, that the changes in the news media environment may 
have decreased journalists' influence over their own practices and increased the influence of media owners.

It can be argued that journalists in small media systems are less autonomous than journalists in the larger countries. Small audience markets and small advertising markets translate into small job markets, which in general means fewer employers, fewer senior positions and fewer alternatives in terms of career routes and progression (Örnebring \& Lauk 2010). All Icelandic media companies are small in international comparison, and as Harðarson states, “staff-shortages seriously limit Icelandic journalists' possibilities for high-class journalism” (2008, 80). Journalists are seldom specialists, which may make them more dependent on their sources, and the small job market can make them less resistant to commercial pressures and ownership power. A small media market like the Icelandic one is also particularly vulnerable to global changes such as the digital revolution or a financial crisis of the magnitude that hit Western economies in 2008.

\section{The impact of the financial crisis}

The financial crisis in 2008 and the subsequent collapse of all major banks in Iceland caused economic and political turmoil in Iceland and spurred massive protests in the country, often referred to as the "pots and pans revolution" (Bernburg 2016). Although the economy has recovered remarkably well (Jónsson \& Sigurgeirsson 2017) there is still considerable social and political instability, witnessed most recently by the early elections following the Panama Papers scandal in 2016 and early elections again in the autumn of 2017. Furthermore, public institutions have not recovered to their pre-crisis level of trust. The media industry was badly hit by the financial crisis, and trust in the news media is low.

According to Guðmundsson $(2016,41)$ the total turnover of the five largest media companies "almost halved between the years 2007 and 2009, measured in fixed prices". The turnovers of the two largest private media companies, 365 Media and Árvakur, plummeted by 48-49\%. According to Statistics Iceland the advertising revenue of the media fell by 68\% from its peak in 2007 to 2009, calculated in 2015 fixed prices (Statistics Iceland 2017). As a result, some publications ceased to exist, and others downsized. Almost a third of the journalist population was laid off, among them many experienced journalists (Jóhannsdóttir 2015; Kolbeins 2012). This sizeable decline seems to have occurred in the individual media outlets with similar force. According to Guðmundsson (2016) 365 Media laid off $22 \%$ of its journalists, RÚV $26 \%$ and Árvakur 31\%, and at other news media outlets $33 \%$ of journalists lost their jobs. Similar declines have been seen in other countries, for example in the United Kingdom, the United States and Australia (Curran 2016).

The Icelandic news media was heavily criticised for its performance in the years leading up to the crisis. The Icelandic Parliament established a Special Investigation Commission (SIC) in December 2008 to investigate the causes of the collapse of the Icelandic banks (Act no. 148/2008). It published a highly critical report in April 2010. The report illustrated that the banks, politicians and public institutions in Iceland were 


\section{STJÓRNSÝSLA}

at fault and that one of the problems was that divisions of tasks between representatives and administrators of governmental institutions often seemed to be unclear, and no one was willing to admit responsibility for mistakes made (Hreinsson et al. 2010). The SIC report also argued that the news media had largely failed in its watchdog role in the coverage of the financial sector prior to the collapse and had instead mainly echoed the positive discourse presented by the PR departments of the banks (Árnason et al. 2010). The Union of Icelandic Journalists established its own committee to review the SIC report and concluded that the critique was, in many ways, well deserved. Professionalism in Icelandic journalism was said to be under-developed and intertwined with the political system and other forces of power, which had been exposed as the prime motors of the financial crisis. The committee also stressed that the working conditions were difficult for journalists, as editorial offices were poorly financed and understaffed (Blaðamannafélag Íslands 2010).

Trust in various institutions in Iceland collapsed following the crisis. In February 2008, a few months before the crisis hit, $42 \%$ of Icelanders said that they trusted the Icelandic Parliament. A year later, the trust had plummeted to only 13\% (Gallup 2017). Trust in other institutions and companies also fell sharply. As Bjarnason (2014) illustrates, trust in most institutions fell particularly sharply in Iceland in comparison to other countries. As he discusses, it is common that public trust in institutions in countries that go through very difficult economic periods falls more sharply than in other countries. For example, trust in parliaments in Europe fell from 43\% in 2007 to $26 \%$ in 2013, but trust decreased considerably more in Ireland, Spain, Greece and Portugal than in France and Germany (Roth et al. 2011).

Given the criticism aimed at the Icelandic media for failing in its watchdog role prior to the crisis, and how trust in various institutions fell drastically, it would not come as a surprise if trust in the media would have collapsed following the crisis. Unfortunately, Gallup in Iceland does not regularly measure trust in the media. However, the company Markaðs- og miðlarannsóknir (Market and Media Research) has measured trust in the media since December 2008. Figures therefore do not exist to compare with the precrisis era, but these numbers can be used in comparison to trust in other institutions in society following the crisis and in relation to international trends. In December 2008, only $23 \%$ of Icelanders said that they trusted "the media" as a whole. Seven other institutions were less trusted, including the government (19\%), the Icelandic Parliament $(18 \%)$, the Icelandic Financial Supervisory Authority (5\%) and the Icelandic banking system (5\%). Interestingly, the survey only asked about one particular media outlet, the Icelandic Public Broadcasting Service (RÚV) television news, and it was tied at the top of the survey alongside the University of Iceland. A very high percentage of the population, or $77 \%$, said that they trusted both (Markaðs- og miðlarannsóknir 2008). Those saying they trusted RÚV's television news were three times as many as those who said they trusted the media in general. In a comparable survey conducted in May 2009 (following the "pots and pans" protests and the fall of the government in February of that year), trust in the media as a whole had fallen from $23 \%$ to an even lower $15 \%$. In the 
years following, trust in the media as a whole has never reached higher than $19 \%$. The only institutions trusted less over this entire period are the Icelandic Parliament, the Icelandic pension funds, the Icelandic Financial Supervisory Authority and the Icelandic banking system (Markaðs- og miðlarannsóknir 2015).

In an international comparison trust in the Icelandic media ranks low. However, many surveys show that trust in the media is declining in most countries, and this can therefore be seen as a larger international trend. When asked about their confidence in "the press" in the World Values Survey (2010-2014), only 36\% of Swedes reported to have a great deal or quite a lot of confidence in the press (World Values Survey Association, n.d.). The same was true, for example, of $42 \%$ of respondents in Germany, 31\% in Spain and 34\% in the Netherlands. The 2017 Reuters Digital News Report (Newman et al. 2017) asked about overall trust in news media, and all Nordic countries apart from Iceland were included in the study. It found that $62 \%$ of Finns had overall trust in news media (the highest of any country in the survey), and the same was true of $50 \%$ of Danes, $49 \%$ of Norwegians and $42 \%$ of Swedes. Trust was considerably lower in many other countries participating in the study, including France $(30 \%)$, and the lowest trust numbers were recorded in South-Korea (23\%) and in Greece (23\%), which, like Iceland, was particularly badly hit by the financial crisis.

Trust in "the media" or "the press" as an institution is one thing, and trust in individual media outlets is another. As seen in Table 3, trust in most Icelandic individual outlets is considerably higher than in the media as a whole from 2009-2016. Trust in RÚV has remained consistently highest during this whole period, from $69 \%-79 \%$.

Table 3. Trust in Icelandic media outlets. Percentage of those saying that they trust the outlets "very much" or "fairly much"

\begin{tabular}{lccccccc}
\hline & $\mathbf{2 0 0 9}$ & $\mathbf{2 0 1 0}$ & $\mathbf{2 0 1 1}$ & $\mathbf{2 0 1 2}$ & $\mathbf{2 0 1 3}$ & $\mathbf{2 0 1 4}$ & $\mathbf{2 0 1 6}$ \\
\hline RÚV news & 70 & 79 & 72 & 75 & 77 & 71 & 69 \\
Channel 2 news & 36 & 44 & 42 & 45 & 44 & 41 & 41 \\
Mbl.is & 54 & 52 & 50 & 51 & 50 & 47 & 41 \\
Morgunblađið & 52 & 46 & 43 & 45 & 46 & 41 & 37 \\
Fréttablađið & 34 & 35 & 37 & 41 & 39 & 35 & 30 \\
Vísir.is & 24 & 30 & 33 & 35 & 35 & 34 & 33 \\
Viðskiptablaðið & 22 & 26 & 26 & 33 & 31 & 26 & 27 \\
Stundin & $\ldots$ & $\ldots$ & $\ldots$ & $\ldots$ & $\ldots$ & $\ldots$ & 26 \\
Kjarninn & $\ldots$ & $\ldots$ & $\ldots$ & $\ldots$ & $\ldots$ & 27 & 31 \\
DV & 4 & 9 & 9 & 10 & 10 & 14 & 7 \\
\hline
\end{tabular}

Source: MMR ... Data not available.

Iceland's economy has recovered remarkably well from the financial crisis in 2008 and surpassed its pre-crisis level in 2015 (Jónsson \& Sigurgeirsson 2017). The advertisement revenue of the Icelandic media has increased during the last decade but is now only 
around $75 \%$ of what it was at its all-time-high in 2007, calculated in fixed 2016 prices (Statistics Iceland 2018). Again, this is not unique to Iceland. The advertising revenue of the media in the other Nordic countries, for example, declined by $15 \%$ in Norway and by 25\% in Finland from 2008 to 2015, in 2008 fixed prices (Ohlsson \& Facht 2017). A comparable figure for Iceland is $23 \%$. Newspapers and magazines suffered more loss than other kinds of media, mostly because of changes in media consumption (Statistics Iceland 2018). Nevertheless, the Icelandic advertising market differs somewhat from the other Nordic media markets as newspapers (and radio) have a much larger share of the advertising "pie" than is the case in most other countries. Despite the spread and popularity of the internet and social media the web is still a relatively underdeveloped advertising medium in Iceland (Menntamálaráđuneyti 2018; Statistics Iceland 2017).

The largest media companies in Iceland have all come through the crisis, and Ohlsson and Facht (2017) note that all three (RÚV, 365 Media and Árvakur) have experienced growth since 2011. The number of employees at all three is nevertheless smaller than before the crisis. The number of journalists working in the media on the whole has still not reached its pre-crisis level (Guðmundsson 2016).

\section{Conclusions}

The aim of this article was to map key developments in the Icelandic media system and assess the changes it has undergone in the first decades of the $21^{\text {st }}$ century. We have illustrated that the Icelandic system is unlike the media systems in the other four Nordic countries in several ways. It can be described as a hybrid of the three models identified by Hallin and Mancini (2004) but arguably does not combine the best of all three. The available studies and data paint a picture of a highly commercial media system but with less-developed journalistic professionalism than in the liberal countries and without the public service requirements and public support of private media that characterises the democratic corporatist countries. Even though the Public Broadcasting Service is comparatively in a strong position in Iceland, research indicates it is less sheltered from commercial forces and political influence than its Nordic counterparts (Karlsson \& Broddason forthcoming; Kristinsson 2012). Remnants of political parallelism from the past have carried over to a new media system moving closer to the liberal model, and Iceland shares similarities with the polarised pluralist countries when it comes to a weak media regulatory body and a tight bond between the political and business spheres (Ohlsson \& Facht 2017; Guðmundsson 2013).

We have also painted a picture of a news media in turmoil in recent years with no end in sight. Whilst working on the present article, one newspaper and one TV talk show station went bankrupt, and a chain of local newspapers ceased publication. Another newspaper and several online sites changed ownership, and a telecommunication company became a news broadcaster and an online news provider (Menntamálaráðuneyti 2018). The financial crisis in 2008 hit the Icelandic media very hard (Guðmundsson 2016). However, it is difficult to discern the extent to which the difficulties it is now facing are effects related to the crisis and the vulnerability of the small Icelandic market 


\section{STJÓRNMÁL

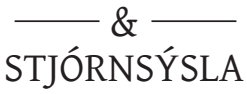

and what is linked to a worldwide trend brought about by the digital revolution. Most likely the difficulties are a combination of both. The limited research and data available on Iceland do suggest that the changes that have transformed the media landscape in the Western world in the last couple of decades (Lee-Wright et al. 2012; Nielsen 2012; Fenton 2010; Currah 2009; Hardy 2008; Herkman 2008; Hallin \& Mancini, 2004) have had similar effects in Iceland as elsewhere. Research indicates that commercialisation has increased considerably in the news (Jóhannsdóttir 2018; Guðmundsson 2013; Karlsson 2004) and that journalism as a profession is under increasing pressure (Guðmundsson \& Kristinsson 2017; Guðmundsson 2012b). Like elsewhere traditional media, especially newspapers, are losing ground, and their business model is being undermined by the sweeping changes of digitisation. And even if particular Icelandic circumstances have led to media ownership powers and political parties being "mixed with each other" as Guðmundsson $(2013,510)$ argues, increasing political parallelism is a trend researchers have also observed elsewhere (Hallin 2009; Currah 2009).

In some ways the impact of the financial crisis on the Icelandic media is similar to the impact the crisis had on the media in other countries. The loss of trust after the crisis is a global phenomenon, and the proportion of journalists laid off after the crisis is comparable to elsewhere (Curran 2016). Ohlsson and Facht (2017) note that cutbacks in personnel have been smaller in Iceland than in the other Nordic media companies in recent years and suggest that this is because Icelandic media companies entered the digital age "with already slimmed down and cost-conscious organisations" $(2017,93)$. However, it is likely that this abrupt downsizing made an already small and vulnerable journalism profession even more vulnerable and less able for example to resist the forces of commercialisation. As discussed, Icelandic media companies are small in international comparison, and even before the crisis hit it was argued that staff shortages seriously limited Icelandic journalists' possibilities for high-quality journalism. It is worth noting that it has been stated that the Icelandic news media has to some extent become more critical in covering political and economic affairs since the financial crisis and that it often does a good job in holding authorities accountable despite limited means (Júlíusson 2017). This has been discussed in relation to the criticism the media received in the SIC report but has yet to be researched. Comparatively, trust in the Icelandic media as a whole ranks particularly low according to the limited data available. It would have been useful to compare trust figures for the media in Iceland to other countries pre- and post-crisis, but, as mentioned, trust in the media was not systematically measured before 2008. Furthermore, the inclusion of Iceland in the larger comparative studies, such as the Reuters Digital News Report, would be helpful to gain more detailed insight from a comparative perspective.

Although the Icelandic media companies have come through the financial crisis, the changes brought about by digital technology have accelerated. There is a tendency to overemphasise technological changes, but, as Preston states, the effects of new information technology "are not intrinsic or fixed, but negotiated or mediated" by the interplay of forces of power (institutional, managerial, organisational and professional) in the 


\section{STJÓRNSÝSLA}

wider socio-political settings of the system (Preston 2009, 163). The committee that looked into the economic situation of private media in Iceland emphasised in its report that media companies are not like any other because of the nature of their business, that is, as watchdogs, providers of information, venues of public debate and mirrors of society and culture. The report also posits that the importance of the editorial work of the news media, not least the verification of information, has become even more important in the digital age. "Professional, objective and independent media are at the foundation of democracy. It is of public interest to uphold the financial strength of the media to enable them to sustain effective editorial offices" (Menntamálaráðuneyti 2018, 10, authors' translation). Though the proposals put forward by the committee are still being debated, the view that some sort of public support is required to secure an independent media and high-quality journalism is clearly gaining ground in Iceland (Guðmundsson 2012b). The Ministry of Education, Science and Culture is reviewing the proposals, and the minister aims to put a bill forward next autumn to the parliament on public support for the media (Friðjónsdóttir 2018; Fréttablaðið 2018). If it goes through, the Icelandic media system will become more like its Nordic counterparts in the democratic corporatist model.

The news media is a vital part of healthy democracies. It is, therefore, of great importance to study the rapid changes that are now taking place. As illustrated in this article, Iceland is absent from much of the key comparative literature in journalism and media and communication studies. As a result, we do not have a clear picture of how it compares with other countries. For example, we need to understand better where the general public is getting its information nowadays (a key focus in the annual Reuters Digital News Report), how journalistic professional practices are changing, how politicians are adapting to the new media landscape, what impact current media ownership is having on the media market, RÚV's current position in the small media market and how social media and the internet are changing journalism and the news media more generally in Iceland.

\section{Acknowledgements}

We would like to thank the two anonymous reviewers for the helpful comments. Moreover we would like to thank Guðmundur Heiðar Frímannsson, Gunnar Helgi Kristinsson, Sjöfn Vilhelmsdóttir, Ragnar Karlsson, Aeron Davis and Ida Willig for their useful feedback and encouragement along the way.

\section{Notes}

1. The owner of 365 Media also has a notable share in Vodafone Iceland, but the Icelandic Competition Authority set as a condition that either the shares in Fréttablaðið or in Vodafone Iceland will be sold within an undisclosed period of time (Samkeppniseftirlitið 2017a).

2 Fréttablaðið was originally founded in 2001 but went bankrupt, and its publication was ceased. It was subsequently taken over and restored in 2002 by the present owners. 


\section{STJÓRNMÁL \& \\ STJÓRNSÝSLA}

\section{References}

Act no. 142 (2008). Act on Investigating the Processes that Lead to the Collapse of the Icelandic Banks in 2008 and Related Events. Reykjavík: Alpingi.

Act no. 38 (2011). Media Act. Reykjavík: Alpingi.

Act no. 54 (2013). Act on Changes to the Media Act no. 38/2011 (Ownership Rules and Improvements). Reykjavík: Alpingi.

Ahva, L., van Dalen, A., Hovden, J.F., Kolbeins, G.H., Löfgren Nilsson, M., Skovsgaard, M., and Väliverronen, J. (2017). “A Welfare State of Mind?”, Journalism Studies 18, 595-613.

Axelsson, K., and Gylfadóttir, E.Ý. (2015). "Mikilvægi faglegrar blaða- og fréttamennsku og hugleiðingar um pað aðhald sem henni er veitt", Lögrétta 11, 46-119.

Árnason, V., Nordal, S., and Ástgeirsdóttir, K. (2010). "Siðferði og starfshættir í tengslum við fall íslensku bankanna 2008”, in P. Hreinsson, S. Benediktsdóttir, and T. Gunnarsson (eds.), Addragandi og orsakir falls islensku bankanna 2008 og tengdir atburdir. Reykjavík: Alpingi.

Bakker, P. (2008). "The Simultaneous Rise and Fall of Free and Paid Newspapers in Europe", Journalism Practice 2, 427-443.

Bakker, P. (2013). "The Life Cycle of a Free Newspaper Business Model in Newspaper-Rich Markets", Journalistica. Tidskrift for Forskning i Journalistik 1, 33-51.

Bernburg, J.G. (2016). Economic Crisis and Mass Protest: The Pots and Pans Revolution in Iceland. New York: Routledge.

Bjarnason, T. (2014). "Traust í kreppu: Traust til Alpingis, lögreglu, stjórnmálamanna og forseta Íslands í kjölfar hrunsins”, Íslenska pjódfélagið 5, 19-38.

Blaðamannafélag Íslands (2010). "Fjölmiðlar og skýrsla Rannsóknarnefndar Alpingis" (The Media and the Parliament Special Investigation Commission's report). Reykjavík: Blaðamannafélag Íslands (The Union of Icelandic Journalists). Available at: http://press.is/index.php/felagidh/frettir/2716fjolmidlar_og_skyrsla_rannsoknarnefndar_althingis

Broddason, P., and Karlsson, R. (2005). "Medien in Island", in Hans-Bredow-Institut (ed.), Internationales Handbuch Medien 2004/ 2005 (pp. 346-367). Baden-Baden: Nomos.

Currah, A. (2009). What's Happening to Our News: An Investigation in to the Likely Impact of the Digital Revolution on the Economics of News. Oxford: Reuters Institute for the Study of Journalism.

Curran, J. (2016). "The Internet of Dreams. Reinterpreting the Internet", in J. Curran, N. Fenton, and D. Freedman (eds.), Misunderstanding the Internet (pp. 1-47). New York: Routledge.

Curran, J., Lyengar, S., Lund, A.B., and Salovaara-Moring, I. (2009). "Media System, Public Knowledge and Democracy: A Comparative Study", European Journal of Communication 24, 5-26.

DV (2009). "11 púsund sögðu upp Mogganum”, DV. Reykjavík: Birtingur.

Engblom, L-Å. (2013). "Public Service Financing in the Nordic Countries”, in U. Carlsson (ed.), Public Service Media from a Nordic Horizon: Politics, Markets, Programming and Users (pp. 93-106). Gothenburg: Nordicom.

Exista (2007). Annual General Meeting: Excecutive Chairman's Statement.

Fenton, N. (2010). New Media, Old News. Journalism \& Democracy in the Digital Age. Sage Publications Ltd. Fenton, N. (2016). "The Internet of Me (and My 'Friends')", in J. Curran, N. Fenton, and D. Freedman (eds.), Misunderstanding the Internet (pp. 145-172). New York: Routledge.

Fjölmiðlanefnd (n.d.). Upplýsingar um islenska fjölmiðla (Information on Icelandic Media Companies). Reykjavík: Fjölmiðlanefnd. Accessed at: http://fjolmidlanefnd.is/fjolmidlamarkadur/eignarhald-a-fjolmidlum/

Fontaine, P. (2009). "Hiring of Oddsson Garners Criticism from Nordic Journalist Union”, Grapevine. Reykjavík: The Reykjavík Grapevine.

Fréttablaðið. (2018). “Tekjutap í breyttu umhverfi”, Fréttablađið. Reykjavík: 365 Ltd.

Friðjónsdóttir, H.D. (2018). “Tillögur fjölmiðlaskýrslu metnar í ráðuneytinu”. ruvis. Reykjavík: Ríkisútvarpið ohf. Available at: http://www.ruv.is/frett/tillogur-fjolmidlaskyrslu-metnar-i-raduneytinu. 


\section{STJÓRNSÝSLA}

Friðriksson, G. (2000). Nýjustu fréttir: Saga fjölmiðlunar á Íslandi frá upphafi til vorra daga. Reykjavík: Iðunn. Gallup (2017). Traust til stofnana (Trust in Institutions). 27.02.2017 ed. Reykjavík: GI rannsóknir ehf.

Gregson, J. (2017). "The Richest Countries in the World”, in Global Finance Magazine. New York: Global Finance Media, Inc.

Guðmundsson, B. (2006). "The Role of Local Media in Sustaining Viability in Rural and Smaller Regional Communities in Iceland”, in E. Aradóttir (ed), Nordic-Scottish University Network. for Rural and Regional Development; Annual Conference Sept. 22-25, 2005, 2006 Akureyri: Háskólinn á Akureyri, 147-159.

Guðmundsson, B. (2009). "Traust á sögulegum grunni: Rannsókn á fréttareglum Ríkisútvarpsins", Stjórnmál og stjórnsísla 5, 295-310.

Guðmundsson, B. (2012a). "Umræðuvettvangur íslenskra dagblaða með hliðsjón af greiningarramma Colin Sparks”, Stjórnmál \& stjórnsýsla 8, 323-342.

Guðmundsson, B. (2012b). The Journalist Union and the Icelandic Media Condition: An Overview. Blaðamannafélag Íslands (The Union of Icelandic Journalists).

Guðmundsson, B. (2013). "Pólitísk markaðsfjölmiðlun", Stjórnmál \& stjórnsýsla 9, 509-530.

Guðmundsson, B., and Kristinsson, S. (2017). "Journalistic Professionalism in Iceland: A Framework for Analysis and an Assessment", Journalism, 1-20.

Guðmundsson, B.P. (2017). "Sigurður kaupir DV í fjórða sinn”, in RÚV Reykjavík: RÚV.

Guðmundsson, F.P. (2016). "Iceland's Media Market after the Collapse of 2008: Fewer Journalists Lighter Material”, Nordicom Information 38, 41-45.

Hallin, D., and Mancini, P. (2004). Comparing Media Systems: Three Models of Media and Politics. Cambridge, UK: Cambridge University Press.

Hallin, D.C. (2009). "Not the End of Journalism History", Journalism 10, 332-334.

Hallin, D.C., and Papathanassopoulos, S. (2002). "Political Clientelism and the Media: Southern Europe and Latin America in Comparative Perspective", Media, Culture \& Society 24, 175-195.

Hardy, J. (2008). Western Media Systems. London: Roudledge.

Harðarson, Ó.P. (2008). "Political Communication in Iceland", in J. Strömbäck, M. Ørsten, and T. Aalberg (eds.), Communicating Politics. Political Communication in the Nordic Countries (pp. 63-82). Gothenburg: Nordicom.

Herkman, J. (2008). “Current Trends in Media Research”, Nordicom Review 29, 145-149.

Hreinsson, P., Benediktsdóttir, S., and Gunnarsson, T. (2010). Aðdragandi og orsakir falls islensku bankanna 2008 og tengdir atburoir. Reykjavík: Rannsóknarnefnd Alpingis.

Hringbraut (2016). "Mannamál með Sigmundi Erni Rúnarssyni. Viðmælandi Óskar Magnússon”. Available at: http://www.hringbraut.is/sjonvarp/klippur/mannamal-oskar-magnusson.

Indriðason, I.H., Önnudóttir, E.H., Pórisdóttir, H., and Harðarson, Ó. (2017). "Re-electing the Culprits of the Crisis? Elections in the Aftermath of a Recession", Scandinavian Political Studies 40, 28-60.

International Telecommunication Union (2017). "ITC Development Index 2017. Geneva: International Telecommunication Union”. Available at: https://www.itu.int/net4/ITU-D/idi/2017/

Internet World Stats (2017). Internet in Europe Stats: Internet User Statistics \& 2017 Population for the 53 European Countries and Regions. Miniwatts Marketing Group.

Johnsen, G. (2014). Bringing Down the Banking System: Lessons from Iceland. Basingstoke, Hampshire: Palgrave Macmillan.

Jóhannesson, G.T. (2009). Hrunið: Ísland á barmi gjaldprots og upplausnar. Reykjavík: JPV.

Jóhannsdóttir, V. (2015). "Women in Journalism: The Situation in Iceland", Nordicom Information 37, 33-40.

Jóhannsdóttir V. (2018) "Commercialization in the Icelandic Press: An analysis of hard and soft news in major print and online media in Iceland in times of change", Journalism, 1-17.

Jónsson, Á. (2009). Why Iceland?: How One of the World's Smallest Countries Became the Meltdown's Biggest Casualty. New York: McGraw Hill Professional.

Jónsson, G. (2014). "Iceland and the Nordic Model of Consensus Democracy", Scandinavian Journal of History 39, 510-528. 


\section{STJÓRNMÁL \& \\ STJÓRNSÝSLA}

Jónsson, Á., and Sigurgeirsson, H. (2017). The Icelandic Financial Crisis: A Study into the World's Smallest Currency Area and its Recovery from Total Banking Collapse. London: Springer.

Júlíusson, P.S. (2017). "Skipulögð eyðilegging íslenskra fjölmiðla”. kjarninn.is. Reykjavík: Kjarninn miðlar ehf.

Karlsson, R. (2004). "Iceland: Mapping the Newspaper Market 1980-2003", in B. Schneider and W. Schütz (eds.), Europäische Pressemärkt - European Press Markets (pp. 223-263). Vienna: Verlag der Österreichischen Akademie der Wissenschaften.

Karlsson, R. (2006). "Radio, TV and Internet in Iceland", in E. Harrie (ed.), Media Trends 2006 in Denmark, Finland, Iceland, Norway and Sweden. Göteborg: Nordicom.

Karlsson, R. (2009). Próun fjölmiðlamarkaðarins, Frumvarp til laga um fjölmiðla, Fylgiskjal l, pingskjal 740-423 mál. 202-372.

Karlsson, R., and Broddason, D. (forthcoming). "Íslenska fjölmiðlakerfið: Markaður, stjórnmál og völd”, in V. Árnason and H.A. Henrysson (eds.), Hvað einkennir islensket lýðređði? Reykjavík.

Kolbeins, G.H. (2012). "Siðferði og starfshættir íslenskra blaða- og fréttamanna”, Djóðarspegillinn 2012. Rannsóknir i félagsvisisindum XIII.

Kolbeins, G.H. (2015). "Icelandic media firms viewed from the perspective of agency theory", Icelandic Review of Politics and Administration 11, 1-20.

Kristinsson, G.H. (1996). "Parties, States and Patronage", West European Politics 19, 433-457.

Kristinsson, G.H. (2012). "Party Patronage in Iceland; Rewards and Control Appointments", in P. Kopecký, P. Mair, and M. Spirova (eds.), Party Patronage and Party Government in European Democracies (pp. 186-205). Oxford: Oxford University Press.

Lee-Wright, P., Phillips, A., and Witschge, T. (2012). Changing Journalism. Routledge.

Markaðs- og miðlarannsóknir (2008). Háskóli Íslands, Fréttastofa Sjónvarps (RÚV) og Lögreglan njóta afgerandi trausts. Gamalgróin vörumerki njóta meira trausts en löggjafar- og framkevamdavaldið. Reykjavík: Markaðs- og miðlarannsóknir ehf (Market and Media Research).

Markaðs- og miðlarannsóknir (2015). "Lítið traust til bankakerfisins og Fjármálaeftirlitsins". Available at: http://mmr.is/frettir/birtar-nieurstoeeur/507-bankakerfidh-og-fjarmalaeftirlitidh-medhminnsta-traustidh-af-helstu-stofnunum-landsins

Markaðs- og miðlarannsóknir (2016). Íslendingar snjallsimavaddir. Reykjavík: Markaðs- og miðlarannsóknir (Market and Media Research).

mbl.is (2016). "Krefjast breytinga á fjölmiðlalögum”, mbl.is. Árvakur.

mbl.is (2017). "Kjarninn gefur út fríblað í samstarfi við Birting”, Reykjavík: Árvakur.

McQuail, D. (1992). Media Performance: Mass Communication and the Public Interest. London: Sage.

Menntamálaráđuneyti (2018). Rekstrarumbverfi fjölmiðla: Tillögur nefndar um batt rekstrarumbverfi einkarekinna fjölmiðla. Reykjavík: Menntamálaráðuneyti.

Moe, H., and Mjøs, O.J. (2013). "The Arm's Length Principle in Nordic Public Broadcasting Regulation”, in U. Carlsson (ed.), Public Service Media from a Nordic Horizon: Politics, Markets, Programming and Users (pp. 75-106). Gothenburg: Nordicom.

Newman, N., Fletcher, R., Kalogeropoulos, A., Levy, D.A.L., and Nielsen, R.K. (2017). Reuters Institute Digital News Report 2017. Oxford: Reuters Institute for the Study of Journalism.

Nielsen, R.K. (2012). Ten Years that Shook the Media World: Big Questions and Big Trends in International Media Developments. Oxford, UK: Reuters Institute for the Study of Journalism.

Nord, L. (2008). “Comparing Nordic Media Systems: North Between West and East?”, Central European Journal of Communication, 95-110.

Nordicom (n.d.). Mediestatistik: Individuals Use of Social Media1 in EU28 and Per Country 2011-2015 (Eurostat). Gothenburg: Nordicom

Ohlsson, J. (2015). The Nordic Media Market 2015. Gothenburg: Nordicom.

Ohlsson, J., and Facht, U. (2017). Ad Wars. Digital Challenges for Ad-Financed News Media in the Nordic Countries. Göthenburg: Nordicom. 
Örnebring, H., and Lauk, E. (2010). "Does Size Matter? Journalistic Values and Working Conditions in Small Countries", 2010 ECREA Conference, Hamburg, Germany.

Preston, P. (2009). Making the News: Journalism and News Cultures in Europe. London: Routledge.

Puppis, M. (2009). "Media Regulation in Small States", International Communication Gazette 71, 7-17.

Roth, F., Nowak-Lehmann, D.F., and Otter, T. (2011). Has the Financial Crisis Shattered Citizens' Trust in National and European Governmental Institutions? Evidence from the EU Member States, 1999-2010, CEPS Working Document No. 343, June 2011 (update).

RÚV (2015). Annual report 2014/2015 (Ársskýrsla 2014/2015). Reykjavík: RÚV.

RÚV (2017). "Samtal”, RÚV. Reykjavík: RÚV.

Samkeppniseftirlitið (2017a). Samkeppniseftirlitið setur samruna Vodafone og 365 skilyrdi til pess að tryggja samkeppni á fjarskipta- og fjölmiðlamörkudum. Reykjavík: Samkeppniseftirlitið (The Icelandic Competition Authorities).

Samkeppniseftirlitið (2017b). Sátt vegna kaupa Fjarskipta á tilteknum eignum og rekstri 365 miðla hf. Reykjavík: Samkeppniseftirlitið (The Icelandic Competition Authorities).

Schweizer, C., and Puppis, M. (2017). "Public Service Media in the 'Network' Era. A Comparison of Remits, Funding, and Debate in 17 Countries", in F.G. Lowe, H. Van den Bulck, and K. Donders (eds.), Public Service Media in the Networked Society. Göteborg: Nordicom.

Statistics Iceland (2017). Advertisement Revenue of the Media Halved Since 2007 in Real Prices. Reykjavík: Statistics Iceland.

Statistics Iceland (2018). The Public Service Broadcaster Holds 21 Per Cent of the Total Media Revenue in 2016. Reykjavík: Statistics Iceland. Available at: https://www.statice.is/publications/news-archive/me$\mathrm{dia} /$ media-revenue-2016/.

Statistics Iceland (n.d.). Population by Municipality, Sex, Citizenship and Quarters 2010-2017. Reykjavík: Statistics Iceland.

Strömbäck, J., and Karlsson, M. (2011). “Who's got the power? Journalists' Perceptions of Changing Influences Over the News", Journalism Practice 5, 643-656.

Syvertsen, T., Mjøs, O.J., Enli, G., and Moe, H. (2014). The Media Welfare State: Nordic Media in the Digital Era. USA: University of Michigan Press.

World Values Survey Association (n.d.). World Values Survey. Online Data Analysis. Vienna: World Values Survey Association. Available at: http://www.worldvaluessurvey.org/WVSOnline.jsp.

Worlds of Journalism Study (n.d). "WJS 2012-2016 Study: Data and Key Tables (Sociodemographic Backgrounds)". Available at: http://www.worldsofjournalism.org/data/data-and-key-tables-2012-2016/ 